\title{
MEMÓRIAS SOBRE A HISTÓRIA DE UMA CIDADE: A HISTÓRIA COMO LABIRINTO
}

Lana Mara de Castro Siman*

\begin{abstract}
RESUMO: Neste artigo, desenvolve-se a argumentação de que a escrita da história de cidades elaborada por meio do diálogo entre a memória e a História pode oferecer possibilidades de aprendermos a nelas nos perder para nelas nos re-encontrar, num tempo labirintítico. A idéia do labirinto é inspirada em Walter Benjamin $(1985,1994)$ e em outros que trabalham nessa tradição teórica e representa uma contraposição à compreensão do tempo histórico forjado na modernidade. Enquanto este é linear, vazio, homogêneo, o tempo labirintítico é múltiplo, não-linear, repleto de possibilidades inscritas nas relações do presente com passado e futuro. Para decifrá-lo, é necessária a aprendizagem da leitura indiciária - dos sinais, dos signos, das ruínas, das marcas, dos gestos, dos silêncios, - deixados pela ação dos homens e relatados pelos seus testemunhos. É, também, em Benjamin que se apóia a idéia de que a história como labirinto é contada pelo narrador que narra a sua experiência histórica. A escrita híbrida da história entre a História e a memória -, base para o desenvolvimento da referida argumentação, é fruto de uma pesquisa com fontes orais e outros conhecimentos históricos, elaborada para uma dissertação de mestrado defendida pela autora do artigo, sobre a história de Governador Valadares, Minas Gerais.
\end{abstract}

Palavras-chave: Leitura Indiciária; Narrativa; Memória; Ensino de História

\section{MEMORIES ABOUT THE HISTORY OF A CITY: THE HISTORY AS A LABYRINTH}

ABSTRACT: In this article, it is developed an argumentation concerning the writing of the history of the cities being elaborated through the dialogue between the memory and the History. This argumentation is based on the idea of this kind of writing offer possibilities of learning to lose ourselves inside the memory and the History and to find ourselves again through them, in a labyrinth time. The idea of the labyrinth is inspired in Walter Benjamim $(1985,1994)$ as well in others who work in this theoretical line. It represents a counter-position to the understanding of historical time constructed in modern time.

\footnotetext{
* Doutora em Didática da História pela Université L.aval, Québec / Canadá. Professora do Programa de Pós - graduação em Educação da UFMG.

E-mails: lanacastrosiman@yahoo.com.br e labepeh.ufmg@gmail.com
} 
While the latter is linear, empty, homogeneous, the labyrinth time is multiple, non-linear and full of possibilities that are inscribed in the relation between the present and past, besides the present and future. To decode it, it's necessary to learn indicting reading - through signals, signs, ruins, marks, gestures, silences, - left by the human beings' action and reported by their testimonies. It is also supported by Benjamin's concept the idea of the history as a labyrinth being told by the narrator who reports his historical experience. The hybrid writing of history - between the History and the memory -, basis for the development of the mentioned argumentation, is constructed by a research made with oral sources and other historical knowledge and elaborated for a master dissertation defended by the author of the article about the history of Governador Valadares, MG.

Keywords: Indicting Reading; Narrative; Memory; Teaching of History

"Saber orientar-se numa cidade não significa muito. No entanto, perder-se numa cidade, como alguém se perde numa floresta, requer aprendizagem”. (WALTER BENJAMIN, Infância em Berlim)

"To know guiding in a city does not mean a lot. However, to lose in a city, as someone who loses in a forest, requests learning". (WALTER BENJAMIN, Childhood in Berlim)

Pode a escrita da História de cidades, elaborada a partir do diálogo entre a memória e a História, oferecer a alunos e professores oportunidades de aprender a se perderem numa cidade? Quais são as ruas, os lugares, as horas do dia e da noite em que os sujeitos tecem fios de outros caminhos e histórias, pouco visualizados por aqueles que chegam com mapas e livros nas mãos? Ou por aqueles que chegam de mãos vazias? Quem são esses sujeitos que podem ajudar a nos perder em caminhos já traçados? O que eles nos dão a ver, escutar e refletir - mesmo sem ter a intenção de fazê-lo - ao narrarem sobre os labirintos da história da cidade? E de que forma o fazem, com que linguagem, com quais imagens, indícios, interjeições, silêncios e esquecimentos?

A escolha da cidade de Governador Valadares, entre tantas outras, para a construção desta escrita se explica pelos laços de perten- 
cimento que me prendem ao lugar e ao fato de se tratar de uma cidade nova, cujos velhos moradores, havendo participado de sua formação, podem ser os narradores de sua história.

Este artigo, em grande parte, é fruto da minha dissertação de mestrado, que teve como motivação principal explorar as possibilidades da relação história e memória para ensino da História de cidades.

No meu imaginário ${ }^{2}$ sobre a cidade de Governador Valadares, assim como no de tantas outras pessoas com as quais convivi diretamente ou não, ou ainda no imaginário propagado (e por vezes que ainda se propaga) por meio dos jornais e rádio, televisão e outros meios de comunicação, a cidade era constituída de representações muito insti-gantes, ao mesmo tempo que estereotipadas: "terra de gente brava", onde havia sempre alguém com uma bala na agulha do revólver, pronto para disparar. Terra em que corria muito dinheiro e, por isso, lugar procurado por quem precisava de trabalho ou por quem desejava enriquecer-se com rapidez. Hoje é conhecida como lugar de mais forte imigração brasileira para a América do Norte ${ }^{3}$.

As suas primeiras imagens da "Princesa do Vale do Rio Doce" eram, a um tempo, da cidade e da região. Região nova, de fronteira, rica em recursos naturais: floresta tropical primitiva, solo rico em recursos minerais, com uma estrada de ferro ligando o sertão ao mar. A história do sucesso, da vitória do homem na ocupação da região e na utilização dos seus recursos sempre foi, no entanto, encoberta por uma espessa cortina de fumaça, ocultando a história da produção dessa vitória.

À época da elaboração do meu trabalho, inquietei-me ao examinar, nos cadernos do meu irmão, o que a escola propunha que ele aprendesse sobre a história da cidade: de Figueira do Rio Doce a Governador Valadares. Nada diferente do que me haviam proposto aprender quando criança: uma história de fatos, acontecimentos, datas e atores que pouco sentido faziam para mim, uma história na qual eu não me reconhecia e não reconhecia os seus atores. Pensei no que poderia contar eu mesma como testemunha de parte da história dessa cidade - seria muito mais do que contavam nas escolas! Muito mais poderiam contar aqueles que teriam vivido mais do que eu e participado mais ativamente do processo de formação da cidade. Decidi-me, portanto, construir outra narrativa histórica, dando voz às pessoas comuns e de quem eu julgava poder extrair valores e possibilidades de aprendizagem de uma outra concepção de História.

Recolhi memórias de trabalhadores da ferrovia, da mica, da madeira, de carroceiros, de pequenos comerciantes; de fiscal de matas, prostitutas e de pessoas presentes no imaginário coletivo da cidade: um 
coronel, um superintendente de uma fábrica; uma professora, um diretor de um jornal combativo, entre outros.

Hoje, o que é proposto para o ensino das cidades certamente mudou. Novas diretrizes para o ensino da História, fundamentadas em inovações historiográficas e pedagógicas, ressaltam a importância do sentido e da criação de significados do conhecimento pelos sujeitos. Enfatizam a importância das práticas e dos procedimentos de investigação para os processos de aprendizagem cognitiva e social dos alunos, por meio da utilização de fontes e procedimentos próprios ao campo do conhecimento ${ }^{4}$. $\mathrm{Na}$ esteira das ou mesmo antecedendo ou, ainda, de forma paralela a essas inovações, encontramos materiais didáticos, práticas de sala de aula com novas abordagens sobre a História das cidades, assim como produções acadêmicas que fornecem elementos de alicerce teórico e metodológico para práticas inovadoras do ensino de História de cidades e/ou locais 5 .

Certamente, diante desse novo tempo do ensino de História, muitas das minhas inquietações mudaram, mas não totalmente. Ainda persistem indagações sobre como criar pontes entre a História e a vida? Como criar, para as novas gerações, nascidas num contexto de mudanças rápidas e numerosas, o sentido do passado e de orientação temporal para as suas vidas? Indago-me sobre como pode a História possibilitar-lhes perceber a multiplicidade de ações dos sujeitos, do estado e das nações no tempo e no espaço, além de suas formas de entrelaçamento? Como favorecer-lhes a visão, nos labirintos da história, dos seus caminhos e tempos múltiplos e pouco lineares? Como aproximar os alunos do outro, do diferente na idade, na cor, na origem social, no sexo, na religião e no modo de vida? Como propiciar-lhes oportunidade de ver e escutar o que nem sempre é dito, lembrado e comemorado na cena pública da cidade ou pelas mídias que freqüentam? Como apresentar-lhes uma escrita diferente daquela que encontramos nos manuais escolares?

Neste artigo, pretendo argumentar que a escrita da história de cidades elaborada por meio do diálogo entre a memória e a História pode oferecer possibilidades de nos perder numa cidade e de nos educar por meio da História. Farei isso apresentando, em linhas gerais, os procedimentos da pesquisa que gerou esta escrita. Em seguida, demonstrarei, por meio dela, que podemos nos perder numa cidade sem medo de não nos encontrar. Isso porque o que ela nos oferece a ler, ver, escutar, sentir, refletir é entretecido com os fios da memória de quem viveu e vive a História. Para efeito deste artigo, elegerei alguns trechos das narrativas, visando a demonstrar e discutir suas possibilidades de educação histórica. 


\section{CAMINHOS METODOLÓGICOS PERCORRIDOS}

Como recolhi as memórias dos velhos moradores sobre a cidade na qual viveram e vivem e de cuja construção histórica participaram? E como entreteci suas narrativas?

Antes de me deslocar para a cidade de Governador Valadares, onde tomei os depoimentos, orientada pela perspectiva da História oral (DEBERT, 1986; LIMA, 1983, CAMARGO, 1984; THOMPSON, 1992; Toledo, 1994; LABERTI, 2005), me dirigi ao Arquivo Público Mineiro, buscando, em seus acervos, estudos e documentos relativos à cidade e à região do Valo do Rio Doce, em que Valadares se situa, como também empreendi as primeiras leituras no campo da história de cidades, da narrativa oral e do ensino de história local e suas fontes orais. Pude, nesse levantamento, traçar uma primeira compreensão do que poderia se configurar como as linhas gerais definidoras do processo histórico de formação e desenvolvimento da cidade, assim como pude confirmar a precariedade de estudos de cunho histórico a respeito dessa região ${ }^{6}$. A produção acadêmica a respeito da História de Minas Gerais concentra-se nas regiões de mineração no século XVIII e nas regiões de maior expressão política, nos séculos posteriores ${ }^{7}$.

Em Governador Valadares, dirigi-me à biblioteca pública, aos acervos de um pretendido arquivo da cidade, fiz um levantamento dos livros escritos pelos filhos da terra, dos poucos documentos existentes. Nessa mesma ocasião, estabeleci alguns contatos iniciais para a elaboração do primeiro mapeamento dos velhos trabalhadores de lá. Nesse momento, foi necessário dedicar horas e horas às conversas com pessoas de quem me fiz amiga para, por meio do relato de suas lembranças, identificar e localizar os velhos trabalhadores de diferentes setores econômicos. Pude constatar que muitos deles haviam morrido, outros já não residiam na cidade e outros estavam tão velhos e doentes que não poderiam trabalhar novamente, relembrando a sua história e a de sua cidade. De posse das informações até então obtidas, tracei os roteiros e comecei a realizar as primeiras entrevistas ${ }^{8}$.

Inicialmente, tomei duas amplas questões como ponto de partida. Como se constituiu a cidade, na percepção de velhos trabalhadores ligados às suas atividades econômicas historicamente mais importantes: a ferrovia, a madeira, a mica, o comércio e a pecuária? Como viveram e experienciaram sua participação na construção da história da cidade?

Essas entrevistas iniciais com trabalhadores (num total de 23) levaram-me a outros depoentes e a outras referências que compareceram 
de forma recorrente no imaginário daqueles trabalhadores: um coronel de polícia, um diretor de usina de beneficiamento de madeira, uma prostituta, um fiscal de matas, entre outros. Buscava o outro lado da História? Não, não era bem isso. Impunha-se a necessidade de captar as relações de dominação e o ser reverso (a transgressão, a resistência), a luta que se travava entre diferentes atores, na constituição do tecido urbano.

Busquei, neste trabalho, penetrar nesse tempo vivido e múltiplo, para captar esses vários momentos e, por meio deles, organizar a história da cidade num tempo diferente do "tempo oficial".

Ao se cruzarem o meu olhar e o olhar dos narradores, a cidade viase revelando pelo seu avesso, pela sua noite, pelas suas margens. $\mathrm{O}$ "perigo de viver" e "fazer a História" relampejam no limiar de vários momentos. História e vida se entrelaçam de tal forma que "o mundo parecia virar de cabeça para baixo". O que estava em cima caiu e vice-versa, tudo se misturando - a luta pela sobrevivência econômica, a luta na construção da história da cidade, a disputa pelo poder, as "forças do progresso" e da modernidade que teimavam em estabelecer suas rupturas com o passado.

O trabalho apareceu como ponto central por onde passavam e se cruzavam as memórias sobre a formação da cidade. No entanto, imagens do trabalho, da experiência e da luta na construção da história foram-se aproximando conflituosamente das imagens de progresso e violência, das transformações rápidas do espaço urbano. Trabalho, progresso e violência não poderiam ser tratados como pontas isoladas. Elas se entrecruzavam.

Após dezenas de outras entrevistas, vivi, de maneira muito aguda, um período de anarquia de pensamentos e emoções. Deparei com uma multiplicidade de histórias; histórias do vivido, do cotidiano, da dominação dos homens sobre a natureza, dos homens sobre os homens. Uma história que não caberia numa fôrma pré-moldada. Lidei, durante algum tempo, com essa "realidade desenquadrada". Idas e vindas, angústias, prazer, medo, buscas incessantes em livros e conversas. Como trabalhar essa história? Como organizá-la, como entretecer os seus fios, como datar vários tempos, as várias imagens? Quem eram seus atores? Que trama estabeleceram na construção da cidade? Como explicá-la?

Foram dias e noites em que me repetia essas questões, relia as entrevistas, até que surgiram as primeiras "imagens da cidade". As imagens não eram como fatos estáticos, tinham dimensões, tinham verso e reverso: a cidade era cheia de labirintos: história estava nas ruas, nas fábricas, nos trilhos da estrada de ferro, no cintilar da mica no chão dos casebres, no traçado da cidade, nas relações entre pobres, ricos e 
remediados. A cidade era medos e sonhos. A história estava na vida... contraditoriamente, acomodada, transgressora, temerosa, ousada.

A partir de então, se eu fosse pintora, creio que não mais pintaria a história da cidade por meio de quadros isolados, dispostos linearmente no tempo. Tentaria, sim, montar um mosaico, em que várias cenas, cores, formas e atores ofereceriam múltiplas imagens, configurando um todo, mesmo que provisório. Nesse mesmo momento, dei-me conta de que algumas imagens iam perdendo a força e outras iam sobressaindo, contraditoriamente, em ruptura ou em continuidade com as imagens anteriores. Essa percepção acabou por me levar a delinear alguns grandes momentos, ou seja, a estabelecer uma periodização, em que a história da cidade emergia de um movimento aparentemente incerto, indeterminado e que, pela força de seus atores e pela força avassaladora do capitalismo, da modernidade e das relações engendraras em seu interior, tomou determinado rumo, entre outros possíveis.

\section{A FORMAC̦ÃO DA CIDADE: MEMÓRIA E HISTÓRIA}

Para efeito deste artigo, apresento encadeamentos de narrativas individuais que denotam a memória coletiva a respeito da história de formação da cidade. Por meio desse encadeamento, evidencio as principais referências em torno das quais Figueira do Rio Doce se desenvolveu: o porto, a estação e a praça de embarque, o mercado. Ressalto, também, outras referências e eventos aos quais os habitantes atribuem significado: a Rua da Direita, o rio, o coreto como local de festas e comemorações cívicas e culturais. Procuro, ainda, entrelaçar depoimentos que evidenciam relações sociais que se mostraram dominantes no processo de ocupação da região, bem como a articulação entre essas relações e o desenvolvimento do distrito de Figueira do Rio Doce.

\section{FIGUEIRA É UMA ESTAC̣̃̃O}

Desde a Proclamação da República até a primeira década do século passado, a região do Vale do Rio Doce permaneceu, por meio do Porto de Figueira do Rio Doce, um lugar de trocas de produtos agropecuários excedentes, vindos do noroeste da bacia média do rio, pelos produtos industrializados vindos do litoral.

Sobre esse período, que se estende de 1808 a 1889, poucas são as memórias transmitidas de gerações para gerações. Não há, na cidade, vestígios que possam testemunhar a presença indígena. Essa "estratégia de esquecimento" - ocultamento - dificulta que se estabeleça qualquer 
relação entre os poucos remanescentes indígenas da região - os crenac e a nação botocuda, que dominava toda a região no século anterior.

$\mathrm{O}$ avanço da estrada de ferro, na primeira década do século XX, vai transformar a região: a floresta é destruída, os índios remanescentes são afugentados, lavradores perdem os frutos do trabalho, com a destruição das plantações e a morte dos animais provocada pela passagem dos trens de ferro. O valor da terra é alterado.

As terras devolutas, a maior parte das quais desocupada, ricas em recursos naturais, cortadas por uma estrada de ferro que as liga ao mar, atraem fazendeiros, comerciantes de madeira e de minerais, e posseiros pobres, que vão formando pequenas roças de subsistência.

Monteiro (1973, p. 153) mostra como sucessivos governos do estado de Minas Gerais encaminham, nas três primeiras décadas do nosso século, a política de ocupação das terras do Vale do Rio Doce. No início do século, aparecem algumas manifestações favoráveis à concessão de terras aos posseiros. Em 1920, o presidente Arthur Bernardes, ao dirigir mensagem ao Congresso Mineiro, assim se refere à situação das terras nas regiões do Vale do Rio Doce e do Mucuri:

Desses, alguns são bem-intencionados e se estabelecem em terras devolutas com intuito de nelas se fixarem definitivamente, construindo habitações regulares e fazendo culturas efetivas. Outros são verdadeiros devastadores de matas. (Citado por MONTEIRO, 1973, p. 154)

Figueira do Rio Doce, a partir dessa época, torna-se um palco privilegiado das transformações que vêm ocorrendo na região. É para Figueira que se dirigem levas de posseiros, de retirantes, de trabalhadores do campo. É em Figueira que residem os “coronéis”. É para Figueira que se dirigem os comerciantes vindos do noroeste da bacia do médio Rio Doce.

Tropeiros, comerciantes e fazendeiros, vindos em sua maior parte de Virginópolis, Sabinópolis, Santa Maria do Suaçuí, Guanhães e Coroaci, deslocam-se da bacia para o vale e para a estrada de ferro que acompanha o rio. Turma de avançamento, maquinistas, foguistas e guarda-freios vão acompanhando os trilhos do progresso:

Em Derribadinha, a construção parou de certa forma aguardando a construção da ponte sobre o Rio Doce. Isso fez com que se formasse, ali, um núcleo de todos os que pretendiam uma melhoria de vida: pequenos negociantes, lojistas, um grupo natural de colonizadores. Quando a linha transpôs o Rio Doce e passou para a margem esquerda, atingindo esta zona, que era inóspita, mas de uma beleza majestosa e arrebatadora, o núcleo de Derribadinha veio para Figueira do Rio Doce. Os pioneiros da Figueira do Rio Doce chegavam, entusiasmados, formando o pequeno povoado. Aqui se 
transformou num centro catalisador, um centro de grandes esperanças. (Raimundo O. Fonseca, citado por SOARES, 1983, p. 77).

Quanto a mim, sem pretensão alguma além da visão acanhada que me domina, quero também dizer algo sobre a Figueira que eu conheci, sem nada ter pra carregar, como canta o nordestino e, digo eu, nem mesmo o sobrenome... Meu pai, do qual só me lembro o primeiro nome, Antônio, era pedreiro de profissão, baiano a quem, na medida do sentimento humano, muito amei. Vim com ele, que acompanhava o trajeto da construção da estrada de ferro (...) Figueira, portanto, aceitou-me em 1909 como dependente total, deu-me seu apoio, merecendo do forasteiro, adaptado, toda a admiração. (JOÃO ÂNGELO DE OLIVEIRA, trabalhador do comércio, 1904 a 1988)'.

Pioneiros e forasteiros assim eram denominados e se autodenominavam os que chegavam a Figueira. Pioneiros são aqueles que vêm da região, trazendo suas famílias, suas posses, suas raízes e vão-se estabelecendo no comércio e nas terras locais. Forasteiros são aqueles que chegam de fora, peregrinando, de mãos vazias, sem sobrenome, solteiros e desagregados de suas raízes, e que oferecem a força de trabalho à ferrovia ou aos donos das terras e do comércio.

Meu pai veio pra cá em 1910; informado por ele e por outras pessoas, eu sei que a estrada de ferro aqui entrou com a placa da estação de Diamantina. (EMÍDIO CIPRIANO, comerciante, na ativa, 74 anos)

A partir de 1910, com a descoberta do minério de ferro em Itabira, os trilhos dessa estrada de ferro serão desviados para atender a outros interesses ${ }^{10}$.

Foi uma companhia que fez um contrato com o governo brasileiro de ligar Vitória a Diamantina, mas quando descobriram aquele Cauê em Itabira, uma companhia inglesa requereu aquilo e o governo da época, que eu não sei qual era porque nem tinha nascido, deu a concessão e que tomou o nome de Itabira Iron. Saíram de Vitória, foi tudo bem até o Naque. Depois eles teriam que subir o Rio Santo Antônio na parte de cá, que significa margem esquerda (porque a gente tem que dar as costas para o nascente do rio, para poder pegar a margem esquerda), e eles, ao contrário, já combinados com a companhia inglesa, atravessaram o rio para poderem ir ao Cauê. Era ilegal, eles não podiam fazer aquilo. Mas outros governos atrás já aceitaram aquilo sem discussão, sem parlamento. Arthur Bernardes foi chegando e cassando os direitos deles. A estrada de ferro ia a Antônio Dias, um lugar vagabundo daqueles, não vale nada, lá era o ponto final da estrada de ferro. (Emídio Cipriano, comerciante, na ativa, 74 anos)

No dia 15 de agosto de 1910, a máquina de número 1 entrou em Figueira e, com a inauguração da estrada de ferro, a cidade do futuro nunca mais parou. 
A festa foi no Hotel dos Pappi. Quando inauguraram a estrada de ferro, não havia ainda estação. Veio um carro pequeno, o carro do médico. Foi ele que serviu de estação. O carro do Dr. Serafim. Da estação até o Hotel dos Pappi, o chão foi forrado com folhas. Depois, como se não quisessem as folhas, mandaram-nos tirá-las e banharam o chão com cerveja Brahma. Era a estrada de ferro Vitória-Diamantina. (OTAVIANO FABRI, citado por SOARES, 1983 , p. 30)

Em 1910, então, o negócio já era só para a Figueira, porque pra baixo não tinha mais necessidade de fazer transporte de canoas porque a estrada de ferro fazia. Trazia toda a mercadoria e levava também os comboios de mercadorias. Aí já começou, em vez de sair toucinhos salgados de dentro das canoas suscitou a subida nos vagões. (EMÍDIO CIPRIANO, comerciante, na ativa, 74 anos)

Figueira vive os prenúncios de um novo tempo: o tempo moderno, da vitória do mecanismo sobre a natureza. Um tempo e um espaço recriados, num ritmo muito rápido, quando comparado ao das tropas e das canoas. Um novo tempo se instaura em Figueira: o tempo dos relógios, dos horários de embarque e desembarque. Mas Figueira ainda viverá dois tempos: o tempo das tropas que continuam marchando do centro até Figueira e o tempo da máquina que se dirige para o litoral.

Havia o suíno. Era um transporte lento, os suínos viajavam da seguinte forma: no $1^{\circ}$ dia em média $10 \mathrm{~km}$, iam aumentando aos poucos, chegando até $2 \mathrm{~km}$. Os animais não podiam estar muito gordos, senão dificilmente se locomoviam. Lembro-me de que meu saudoso pai, o Zé Paca, lá no Santana do Onça, hoje Coroaci, dedicava-se a criar suínos. Comprava, invernava durante alguns meses e quando atingiam a meio-engorda, tocava-os para Figueira do Rio Doce e embarcava-os pela estrada de ferro Vitória-Itabira para as várias localidades, em direção ao Espírito Santo. Isso quando não conseguia vendê-los aqui mesmo, na Figueira. Eu mesmo, aos 10 anos, aqui vim ajudando, sendo o meu trabalho de chamar porcos. Esse trabalho consistia em colocar dois bornais de couro no ombro e seguir na frente atirando grãos de milho, pela estrada e ao mesmo tempo cantando: "nego.... nego...." Os suínos chegavam até a correr. (HELVÉCIO S. RIBEIRO, citado por SOARES, 1983, p. 45)

A população de Figueira cresce, com a inauguração da estação. Além de pessoas vindas do Espírito Santo, do Nordeste e da Bacia do Rio Doce, vieram também estrangeiros, italianos, espanhóis e, posteriormente, sírios e libaneses, que se vão estabelecendo: comércio de gêneros alimentícios, madeiras, construção, fábricas de tijolos e telhas...

Com o advento da via férrea, já notamos a presença de muitas famílias, que vieram para ficar e participar de nossa vida comunitária. Também notamos a 
presença de representantes de outras raças. Era dono da antiga Padaria do Santiago o Sr. Jorge Primo, sendo verdureiro o muito conhecido Salomão, que muitos anos depois regressou à sua terra de origem. João Simão e Dona Germana. Um grupo regular de representantes de sangue italiano. Thomas e Domingos Pappi, madeireiros; Dona Maria Camisassa, nossa costureira; Júlio Deladone, oleiro; João Walfrê, antigo dono do terreno onde hoje estão os bairros Nossa Senhora das Graças e Santa Helena; a família Fabri; Júlio Cipriano, nosso sapateiro. (JOÃO ÂNGELO DE OLIVEIRA, trabalhador do comércio, 1904 a 1988)

\section{A DEMARCAÇÃO DO ESPAC̣O DE FIGUEIRA DO RIO DOCE}

Figueira é apenas uma rua - a Rua da Direita, que segue sinuosamente o rio. Nela, uma praça de embarque. Pioneiros e forasteiros - tropeiros, fazendeiros, madeireiros, ferroviários, pedreiros - estão todos na Rua da Direita. No alto, uma igreja, cercada de mata:

Quando chegamos aqui, não sabíamos se havia igreja. Mas já havia uma pequenina, lá onde está a catedral. Estava escondida no meio da mata. Fora construída pelos Capuchinhos de passagem por aqui, rumo a Diamantina. Fomos procurá-la. Havia também casa dos padres. O Santo Antônio estava lá. Foi achado no rio, pelo pai de Quintiliano Costa. Ele foi pescar e pescou a imagem. Doou-a para a igreja, que recebeu o nome de Igreja de Santo Antônio. Para chegar lá, tivemos que fazer a estrada. A mesma que continuou até hoje. (OTAVIANO FABRI, citado por SOARES, 1983, p. 31)

A mata envolve Figueira. Todos sabem que ela começa no rio e se alonga do porto à igrejinha e desta à estação. Mas ninguém sabe onde termina Figueira do Rio Doce. As terras são devolutas. Fazendeiros, tropeiros vão legitimando as terras ao redor. Acuada, Figueira vai perdendo espaço, a estrada de ferro solicita a Peçanha a demarcação das terras do patrimônio.

As terras do patrimônio - 60 alqueires em volta da estação -, um semicírculo interrompido pelo Rio. O Centro de Figueira é deslocado do Porto das Canoas para a estação da estrada de ferro.

Nos limites do arraial, os pastos para as tropas, os restos de uma tentativa malograda de industrialização, uma serraria, um latifúndio com a sua boiada:

Papai contava que, em 1914, deu um furacão aqui. Essa mata foi toda posta no chão sem gastar machado. Durou 5 minutos. As casas que tinham aqueles encaixes de madeira, tudo bem-feito, rebentaram aquilo que ficou todo mundo sem casa, sem coisa nenhuma. A sorte é que não choveu, foi só vento, chuva de vento. Pegou 3 vagões da companhia de estrada de ferro e soltou por essa linha abaixo. A fazenda do Ministério tem uma lagoa lá no canto. O telhado dessa fábrica de banha foi parar todo lá, por cima da lagoa. Foi uma 
coisa tremenda. No dia seguinte, todo mundo foi ver daquele morrinho da catedral os morros todos. Porque não conheciam os morros não. Era tudo mata muito grande, muito pesada. (EMÍDIO CIPRIANO, comerciante, na ativa, 74 anos)

Teve um ano em que deu uma tempestade aqui, foi em 1913. Casas cobertas de telha, o vento arrancou tudo e ficou todo mundo no tempo. E as casas encheram de água e de pau dessa grossura. $\mathrm{O}$ vento arrancava e jogava de raiz pra cima. Vagões, que estavam na estrada de ferro, o vento tocava eles pra aqui abaixo. Saía doido correndo por aí afora. As folhas de zinco que cobriam as casas brigando no ar, uma batendo na outra. E deu uma confusão aqui que quase arrasou com tudo aqui, em 1913. Tempestade brava que deu aqui. JOSÉ DE ALMEIDA, mestre-de-obras, na ativa, 70 anos)

1913 ou 1914? Choveu ou não choveu? O fato é que Figueira se revelou. Morros pequenos e suaves: os limites de seu horizonte. Uma planície extensa: o espaço a ser ocupado. O rio correndo para o mar, largo e caudaloso. Do outro lado do rio, a Ibituruna: o maior mirante do Vale: $1.230 \mathrm{~m}$ acima do nível do mar.

Figueira está plantada num tabuleiro do Rio Doce, num campo extenso, desabitado, uma floresta virgem do sertão do Leste mineiro. À topografia do lugar será ligada a idéia de moderno, de ser uma cidade do futuro, diferente das cidades antigas e "estagnadas" de Minas. Figueira é moderna - suas maiores riquezas são visíveis, estão acima da terra: serras resplandecentes, árvores centenárias.

O arraial está crescendo. O espaço descortinado pelo vendaval ganhará seu primeiro desenho. Medido, dividido, demarcado. Outras ruas nascerão da primeira. Linhas retas se oporão à sinuosa Rua da Direita. A cidade está-se afastando do rio. Sua ocupação deverá obedecer a um plano. Normas preestabelecidas definirão o cumprimento e a largura dos quarteirões, dos passeios, das ruas, das avenidas, do afastamento das casas umas das outras, e destas da rua. A cidade quer ser moderna:

Figueira está edificada sobre um solo muito plano, tendo suas ruas traçadas e demarcadas até $2000 \mathrm{~m}$ de extensão. A orientação das ruas, que se cortam todas em ângulo reto, é Sul-Norte, Leste-Oeste. Foram projetadas 67 ruas, quase todas demarcadas, embora não em toda extensão e divididas em 177 quarteirões. A largura das ruas é de $20 \mathrm{~m}$ e a largura da avenida que corta todas as ruas transversais, de Sul a Norte, é de $30 \mathrm{~m}$. A área demarcada é de 300 hectares. (GRESBRECHT, 1936, p. 83)

Serra Lima tinha o curso primário, era muito inteligente, desenhava muito bem. Então, arranjou balizas; ele tinha poder econômico muito bom. O furacão já tinha jogado tudo no chão, eram só capoeiras. Quando foi em 
1926, a medição ficou possível. Então ele começou a fazer os picadões e foi traçando. Eu me lembro, nós éramos meninos e fomos caçar passarinhos lá por baixo, estavam aqueles quarteirões capinados. Tudo direitinho. Nós falamos com ele:

- Ô Serra Lima, pra quê essa capinada?

- Isso vai ser uma grande cidade e vai servir para vocês. Eu desejava estar vivo para contemplar junto.

- Então, para evitar aquelas casas como na Prudente de Moraes, todas cheias de curvas, vou fazer isso de um modo que querem quiser construir platibanda pode botar na divisa, mas quem não fizer uma platibanda vai ter que afastar 5 metros pra dentro do lote. E traçou. Nos levava sempre nós éramos meninos, estudávamos, íamos lá ver os mapas deles que ele estava levando mapa pra frente. Mas ele mesmo assim foi cuidadoso. Porque aquela rua Prudente de Moraes, cheia de curva, aquela coisa toda, ele procurou em volta da estação essa avenida aqui. Ele pegou, por exemplo, da estação, ele traçou aquela rua Barão do Rio Branco até na Israel Pinheiro. Depois ele traçou a $\mathrm{BH}$ até na Israel Pinheiro. Ele traçou a Peçanha até na Israel Pinheiro. Parou ali e traçou a $\mathrm{BH}$. E dali ele foi mandado pra fora, pra outro lugar qualquer. (EMÍDIO CIPRIANO, comerciante, na ativa, 74 anos).

O planejamento do espaço urbano parece tanto um modo de evitar ruas estreitas e sinuosas e construções fora dos padrões, que pudessem retirar de Figueira a possibilidade de ser moderna, quanto uma tentativa de disciplinar o crescimento da cidade, que vinha sendo feito em meio à violência, à pressa e à competição impiedosa.

$\mathrm{Na}$ direção dos caminhos das tropas, além dos limites traçados, outra parte da cidade também vai-se desenvolvendo: a zona boêmia.

Nesse tempo, só havia a Rua Prudente de Moraes, a mais antiga, e as Ruas Peçanha e Sá Carvalho. Havia também a Rua de Sabugo, mas era a zona boêmia, onde tombou muita gente assassinado. Era ali mais ou menos onde é a Rua São Paulo. Havia ainda a Rua Torresmo. Tanto essa quanto a do Sabugo eram saída para Peçanha. Tudo o que vinha do Noroeste para Figueira passava por essa rua. JOSÉ CHAVES REIS, citado por SOARES, 1983, p. 36)

Os trabalhadores esmeram-se na construção da cidade, talhando a madeira, moldando tijolos e telhas, aprumando paredes e construindo portas e janelas, telhado e móveis:

Começou aqui as olarias, fabricando tijolos de alta qualidade, artesanal. Teve aí Nicolau, Alfredo Fabri e outros que... Alfredo Fabri tem tijolos requeimados em casas aqui em Valadares, como na Rua Prudente de Morais, de 1920 para 86, tem 66 anos, está lá, até hoje, igual pedra, de tão bem-feito. Era um tijolo requeimado. E tinham os fazedores de telha colonial. Aí as casas, mesmo de madeira, recebiam o telhado, recebiam tijolos bem-feitos. E outras casas depois foram surgindo. A mão-de-obra era fácil. Tỉnha muita 
gente com muita especialidade para trabalhar, marceneiros, carpinteiros... Eles vinham de toda parte. A gente não sabe nem de onde vinham. $\mathrm{O}$ maior número de pedreiros de boa qualidade veio de Aimorés. De Aimorés foi de onde vieram os melhores pedreiros que pousaram por aqui. Marceneiros vieram diversos. Móveis muito bonitos, muito bem-arranjados, tudo muito bem-feito. (EMÍDIO CIPRIANO, comerciante, na ativa, 74 anos)

No trabalho manual, a combinação da força física com o senso do belo. Com as mesmas mãos com que tombaram árvores centenárias e transportavam as toras, serravam e talhavam a madeira. Em troca, o dinheiro minguado:

Eles serravam aquilo até na mão, os estaleiros. Naquela época, não tinha serraria, depois é que apareceu a primeira, de um genro da família Cabral, onde foi esse cemitério antigo, do Sr. Pobel. Dali começaram a sair as primeiras tábuas. Mas como o povo no mato serrava com a mão, traziam e vendiam muito mais barato, o sr. Pobel exportava a dele lá pra Vitória, enquanto os de cá recebiam do sujeito da roça. Tinha indivíduos que serravam tão perfeito que parecia que era uma serraria que tinha feito. Uma coisa perfeita... lindo, lindo. (EMÍDIO CIPRIANO, comerciante, na ativa, 74 anos)

\section{FIGUEIRA É UM MERCADO}

Figueira está crescendo: comércio de cereais, compra, venda e encomendas de todo tipo de mercadorias. Lojas grandes e pequenas, armazéns, pequenas oficinas, as primeiras tentativas de industrialização, outras ruas nascem da primeira. Gente que chega, gente que parte, produtos embarcados, produtos desembarcados. Período de crise, falências, disputas, alegrias, mortes violentas vão se sucedendo na história do lugar.

O comércio foi sempre muito ativo. O Sr. Nicolau tinha um pasto aqui de 10 alqueires de terra. Tinha dia que tinha 800 burros no pasto, que vinham trazendo café, toucinho, etc. e tinha uma vantagem, não tinham fazendeiros grandes aqui não. Fazenda grande só tinha uma aqui, de João Lopes da Silva. Os restantes eram de 5, 10 alqueires de terra; aquilo era um movimento bonito. Quanto eu cheguei aqui, em 1924, a gente olhava as lojas eram todas cheias, tudo bacana. (EMÍDIO CIPRIANO, comerciante, na ativa, 74 anos)

Eu vim de Peçanha para Figueira do Rio Doce no dia 21 de março de 1927. Comprei uma casinha de residência na rua ainda sem nome oficial, por cento e cinqüenta mil réis. Multipliquei a metade da casa em loja comercial de tecidos, calçados e armarinho. No ano seguinte, abri outra casinha de bebidas e cereais, capados, toucinho dos tropeiros e exportando para Vitória, no Espírito Santo, e para Santa Bárbara. (FIRMINO B. DOS SANTOS, citado por SOARES, 1983, p. 5)

Quando eu cheguei aqui, já tinham os ranchos de tropa. Cada atacadista! O chefão daquela ocasião era o Sigismundo Costa, Seleme Hilel, Sinval Coelho. Tinha os ranchos para dar abrigo aos tropeiros. Eram muitos tropeiros. 
Aquilo era política. Cada um desses donos de rancho fazia questão de oferecer mais vantagem. Havia uma competição entre eles. Porque ali, os que batiam a cara naquele rancho eram obrigados a vender pro dono do rancho. O café, o feijão, o toucinho. Eles eram atacadistas na cidade e por isso já tinham onde armazenar o sal, o querosene, tudo que era industrializado. (GERALDO BENTO, mestre-de-obras, 70 anos)

A burguesia comercial de Figueira vinha se constituindo e chegava à violência pela dominação do mercado:

Era uma correria! Brotava gente de todo lado. Cada qual querendo a preferência. Eu mesmo fui, várias vezes, cercar a tropa e pedir a preferência, mandado pelo Said. Os maiores compradores eram: Mafra \& Irmãos (eles tinham várias casas de comércio), Said Hilel, que foi assassinado por ambiciosos concorrentes do comércio. Na época, foi um choque enorme. Eu trabalhava com ele. Sua morte me causou grande revolta, passei mal. Estava tão revoltado que deixei escapar meus sentimentos com palavras imprudentes e amargas contra tal absurdo. (JOSÉ CHAVES REIS, citado por SOARES, 1983, p. 36).

Eu acho que Figueira teve um período muito tranqüilo. Talvez lá pra 1924, mataram aquele filho do Peixoto, no lugar que se chama Figueirinha, onde é hoje a Rua São Paulo. Então, daí pra cá, a coisa piorou. Mas piorou porque começou a entrar muita gente. Porque talvez, em 1924, o comércio era mais desenvolvido, quando cito os tais Mafra. Aí começou a aparecer muita gente. Os lugares velhos, sem mudanças, eles são cheios de compadres e comadres, de primos e tios, e então não há muitos casos de violência. Mas desde que começou a entrar gente pra trabalhar... também depois começou a exploração da madeira, da mica... aí começou a vir gente de todo lado do Brasil, especialmente do Nordeste e daqui do centro. (JOÃO ÂNGELO DE OLIVEIRA, trabalhador do comércio, 1904 a 1988)

Nessa época, o café, entre todos os produtos da região, domina o comércio de Figueira, que é um mercado no cruzamento de caminhos. Um mercado que se articula com outros mercados por uma rota comercial: a ferrovia. Sua função é comercializar, mandar par afora dos estreitos limites da região os excedentes ali produzidos. Vitória e o Rio de Janeiro são mercados certos para o consumo ou que de lá passam a integrar o circuito do mercado internacional:

E o movimento grande aqui era do café, porque o café vinha de toda parte para aqui. Depois que pegava Santo Antônio do Porto, Coroaci, Brejaubinha, Peçanha, São João Evangelista, aquilo era café puro. E desciam tudo nas tropas de burro. Vinham para essa região aqui. (EMÍDIO CIPRIANO, comerciante, na ativa, 74 anos)

Em 1929, a saca de café valia 60 contos. Mas houve um craque internacional, um craque na bolsa de Nova York, e a saca de $60 \$ 000$ passou a valer $6 \$ 000$. 
Todo mundo ficou arrasado, inclusive a firma Mafra \& Irmãos, que, em 1930, faliu. (FONSECA, 1987, p. 82)

As disputas em torno da posse da terra e de exploração de seus produtos vão-se acirrando e, nesse processo, Figueira do Rio Doce transforma-se, aos poucos, num palco privilegiado dessas contradições:

Mesquita e Mafra eram duas famílias que existiam em luta permanente na região. A posse da terra era um dos fatores. Isso aqui era tudo do Estado. Eram terras devolutas. Quando começou a estrada de ferro, começou o problema dos dormentes. A disputa para venderem dormentes para a estrada de ferro. Aí veio um crescimento populacional e isso dava a eles a oportunidade de criarem uma corrente de um lado e uma corrente do outro. - "Você quer, mas eu também quero. Você não vai pegar o contrato, quem vai pegar sou eu”. Disputavam mesmo. Disputavam e consumiam, mataram muito de um lado e do outro. Então, eles aliciavam homens. É o mesmo fenômeno do oeste americano. (...) Teve uma frase em que se chegava aqui na região e era a lei do mais forte. (CORONEL PEDRO FERREIRA DOS SANTOS, 72 anos)

\section{NA PRAÇA DE EMBARQUE}

A Praça de Embarque é uma Praça do Sertão: bravura, esperança, força, amor e ilusões; poeira e redemoinhos... "o diabo no meio da rua". Amansadores de burros e cavalos bravos exibem sua força e destreza. h, boi! h, boil ressoa longe o aboio. A boiada vai seguindo para os pastos dos Cabrais... As portas das casas se fecham, a poeira sobe alto. De longe se ouve o tilintar dos cincerros. Cavalo madrinha na frente, fitas coloridas no pescoço - são as tropas vindas do "centro". h... nego... nego... gritavam os tocadores de porco -, 600, 800 porcos embarcam para Vitória e, dali, para o Rio de Janeiro.

Nos limites do arraial, gigantescas toras são derrubadas e levadas para a serraria de Francisco Pombel, movimentada por máquina a vapor de carvão vegetal. A madeira entrava bruta e saía transformada em dormentes e pranchões. De lá eram transportadas para a Praça de Embarque.

E era tarefa gigantesca o seu transporte para os estaleiros ou serrarias locais ou para o estacionamento de embarque ferroviário. Tão gigantesca quanto primária tal tarefa, posto que assenta uma extremidade das toras num "carretão", ou numa "zôrra", estes eram puxados por dez ou mais juntas de bois que, fustigados a ferrão por candeeiros esbravejantes, babavam de exaustão pelo esforço hercúleo a que eram coagidos. (FONSECA, 1987, p. 45)

A Praça de Embarque é também um lugar de chegada e de partida. "A moçada, principalmente, enfeitava-se para ver a chegada dos trens de 
passageiro" (Antônio Sales de Fraga citado por SOARES, 1983, p. 11). Na Praça de Embarque, chegam as notícias de fora, ligando Figueira aos processos políticos do país. Uma vez, a Praça transformou-se numa praça de guerra. A estação foi tomada, pessoas foram comandadas. Os capixabas que resistiram vieram presos em vagões de bois. Era a Revolução de 30. Para alguns, era um sonho de mudança:

Eu cheguei aqui, de Caratinga, no dia 4 de outubro de 1930. À noite jogamos pôquer. Eu falando só na revolução, que ia ter uma revolução. Quando foi na hora de embarcar, o meu cunhado José Bichara falou: - "Você está falando em revolução, rebentou a revolução no Rio Grande do Sul". eu então, fui para a estação, falei com o agente, um alemão: - o trem agora só sai na hora que eu mandar, "Mas o senhor é passageiro, o senhor não é da chefia". Mas o chefe agora sou eu. Entusiasmado, estava louco com a revolução. Eu achava que, depois de uma revolução, isso mudava tudo. Que o Brasil ia ser o Brasil que eu sonhei com ele. Sonhei tanto que acabei fichado como comunista. Eu sonhava com uma cidade cheia de chaminés. Daqui a Aimorés, fui pegando gente aí pelo caminho, botando bandeira vermelha e parando com carabina. Uma multidão de gente e fomos para Aimorés, em 1930. Eu era getulista. Fui getulista desde 29. A Revolução foi em 30. Eu já era getulista. Houve a revolução e nós vencemos foi uma revolução de conversa, porque foram poucos tiros. Houve uns tiros lá em Aimorés, houve umas mortes aí. (GENÁRIO, trabalhador do comércio, 73 anos)

\section{Para outros, era algo desconhecido:}

A única coisa que eu sei da revolução de 30 é que o coronel Amaral desceu aqui nessa estação. E pegou a polícia de Minas Gerais e passou... Chegou e tomou conta da estrada de ferro. E aqui ele andou arranjando muita gente pra estrada também e levou para Aimorés. Lá em Aimorés, parece-me que tinha uma meia dúzia de soldados, ele prendeu os soldados, e botaram num carro de boi e mandaram para cá. A única coisa que eu me lembro aqui foi dos sujeitos no carro de boi. O coronel Amaral, pra entrar no Espírito Santo, fizeram uma conexão na divisa do Espírito Santo com Aimorés e eles se renderam. Mas os capixabas fizeram uma barreira em Baixo Guandu, deram tiro pra desgraçar lá. O coronel Amaral com a força mineira cortaram na bala até... Eles prenderam todos. Eles vieram presos no carro de boi. foi a única coisa que eu vi com os meus olhos, foram eles presos no carro de boi. (SIZENANDO RIBEIRO, empalhador de móveis, 84 anos).

Os trabalhadores de Figueira têm outras lembranças da Revolução: trabalhadores se escondiam, temendo a convocação para lutar por uma "revolução" em que percebiam somente as manobras militares e a prisão das pessoas a ela contrárias:

Em 1930, quando houve a primeira revolução aqui em Figueira do Rio Doce, hoje Governador Valadares, no tempo de Getúlio Vargas, o lugar ficou todo 
vazio. A maior parte dos homens corriam todos e se escondiam. Lá na Ibituruna, no tempo em que eu morei lá, corriam todos e se escondiam lá em casa. De noite, corriam pra dentro do mato. De dia, eles se aproximavam. (SIZENANDO RIBEIRO, empalhador de móveis, 84 anos)

\section{E o narrador continua:}

Esse trecho que nós estamos aqui, por aí afora, era mata virgem. Na revolução de 30, cismaram em fazer um campo de aviação aqui. Então pegaram todo mundo que andava aí pelas ruas, mulheres, homens, e trouxeram pra cá, para arrancar a mata aqui, derrubar árvore. Foi aí que eles abriram tudo. O campo nunca funcionou porque a revolução acabou. Qualquer camarada que vissem na rua que não estivesse trabalhando, eles traziam pra cá a força. (SIZENANDO RIBEIRO, empalhador de móveis, 84 anos)

Mas a Revolução não era a única coisa vinda de fora da qual o figueirense se escondia:

Mas uma coisa interessante que tinha que correr era outra. Todo mundo tinha um negocinho qualquer. Negócio que não valia nada, mas tinha. $\mathrm{Na}$ ocasião em que o fiscal batia aqui para apanhar os impostos, nós fechávamos e íamos caçar. Todo mundo ia caçar. Ele chegava aqui, ficava 3 dias, não encontrava ninguém, ia embora. Era o fiscal que vinha cobrar impostos para os fundos de Peçanha. (SIZENANDO RIBEIRO, empalhador de móveis, 84 anos)

\section{NAS RUAS}

Nas ruas de Figueira, seus moradores muito cedo foram apreendendo quanto custa a solidariedade humana, numa sociedade em que se interpõem, entre os homens, instituições que exercem a dominação sobre a vida cotidiana.

Aqui nunca teve funcionário da Prefeitura de Peçanha. As ruas aqui eram limpadas pela polícia. A polícia obrigava o sujeito que andava pela rua a limpar a rua. A polícia aqui saía intimando o pessoal pra enterrar o sujeito que tinha morrido. Se a polícia não prendesse o sujeito e o levasse pra enterrar o defunto, ele apodrecia no meio da rua. Às vezes, matava um, podia ser no meio de cinqüenta, ninguém viu. Ir daqui no Peçanha a pé, debaixo da mata, pra ser testemunha lá... desse jeito, ninguém viu nada. Naquele tempo tinha que ir no Peçanha. O prisioneiro ia a pé e o soldado ia a cavalo. Passava no meio das matas, naquele trilhozinho, pegando febre. (SIZENANDO RIBEIRO, empalhador de móveis, 84 anos)

Aqui não era cidade, não. Quando eu vim para cá, ali onde era o mercado, ali era pura tora. Tora, malvarico, vassoura. Onde tinha um pedacinho de rua era mesmo na estação. E a estação era bem distante de onde é hoje. Essa rua direto com a Israel Pinheiro, era mata de um lado e de outro. Eles matavam muita gente aí. Por cima daquelas toras aparecia gente morto. Apareceu um homem morto lá em cima das toras, a pobrezinha da mulher morava lá em 
cima de onde mataram ele. Em vez dela ficar caladinha, enfiou a colher enferrujada. Eles acabaram com ela no porrete. Acabaram com ela de tanto bater. E a polícia não apurava. Não via, ninguém contava. A mulher inventou de falar, só que com aquele porrete que matou o homem eles mataram ela de coro. Ninguém era bobo de falar. (SEBASTIANA, trabalhadora da mica, aposentada pelo FUNRURAL, 74 anos)

\section{NA FÁBRICA DE BANHA}

Em 1912, a construção de uma fábrica de banha em Figueira é a primeira tentativa de industrialização do Vale do Rio Doce. Uma visão de progresso, representada pelo aproveitamento do suíno, "matéria-prima" da região. $\mathrm{Na}$ festa de inauguração, uma cena de violência sacode a pacata Figueira: um embate extremo entre a pobreza e a riqueza, entre o capital e o trabalho, entre o sonho e a desesperança:

Teve um acontecimento que foi triste. Uma firma do Rio de Janeiro veio para aproveitar todos esses porcos que vinham e abriu uma fábrica de banha ali na Filadélfia. Tem um casarão lá, ainda sem rebocar, de tijolo. Vocês podem ir lá que ainda está por lá até hoje. O porco que ela matou foi só o da festa de inauguração. Tinha um empregado que trabalhava lá, mas ele era um sujeito relaxado, sujo. E o patrão pediu que ele fosse limpinho na festa. Era pra todo mundo a festa. E ele foi sujo e o patrão chamou a atenção dele por aquilo. Tinha gente do Rio de Janeiro, gente importante, todos para a inauguração. Ele foi em casa, mudou a roupa e veio impecável. Perguntou se estava bonito e deu uma apunhalada no sujeito e o matou. Então, essa fábrica ficou sendo assunto encerrado naquele dia. (EMÍDIO CIPRIANO, comerciante, na ativa, 74 anos)

\section{NA BEIRA DO RIO}

Das águas do rio viviam muitos dos trabalhadores da cidade. Nas águas do rio, muitos inspiravam seus sonhos, outros perdiam suas ilusões: Essa cidade aqui era abastecida de água do Rio Doce. Eu mesmo tive uma freguesia aí de abastecimento de água do Rio Doce. Apanhava numa cartola e abastecia a freguesia. Eu ia pro comércio, para os armazéns pegar carreto. Foi assim que eu pude criar meus filhos. (JOSÉ LUIZ, ex-ferroviário, 78 anos)

Eu era tintureira e lavava um terno por 3 cruzeiros, não é 3 mil cruzeiros. Lavava, passava e engomava uma calça de brim por 200 réis. Fazia isso tudo na minha casa com tudo meu. E as casimiras? Eu pegava a bacia e enchia de casimira, ia pro rio às $5 \mathrm{~h}$ da tarde. Tava escuro às $5 \mathrm{~h}$. Eu levava uma lamparina e uma caixa de fósforos. Furava um buraco na beira do barranco e enfiava a lamparina lá para a maré não apagar e para iluminar. Não tinha banco. Eu ajoelhava na pedra e lavava 10, 12 ternos ali. Num belo dia, eu fiquei muito triste porque eu tinha um vestido novo e fui lavar ele com as casimiras. Eu dobrei o vestido e ajoelhei por cima dele para não doer os meus joelhos. E tô lavando. Tinha uma cerca lá e eu 
ia dependurar as roupas na cerca para, quando eu voltar, eu poder agüentar levar para casa. Quando eu voltei, cadê o vestido? Foi embora. Um vestido de passeio. Um vestido comprado com tanto sacrifício. Eu fiquei tão triste! Quanto eu tinha de trabalhar para comprar outro vestido! E assim a luta vem. Lavando um terno, um paletó e uma calça por 3 cruzeiros, mas não três mil como é hoje. E de forma que eu vivia aqui, trabalhando, lutando, mas venci. Carregando água na cabeça como eles falam - "Vai Maria carregando a lata d'água na cabeça". (MARIA, exlavadeira, 1914-1988)

\section{NO CORETO}

O coreto era o local das festas onde a banda tocava, a procissão passava, os políticos discursavam e os velhos, os jovens e as crianças se encontravam. Do alto do coreto, podia-se enxergar toda a cidade. O coreto era o "ponto mais livre" de Figueira.

O coreto da avenida fui eu quem construiu. Quando fui jogar futebol em Aimorés, vi lá um coreto muito bonito, fiquei entusiasmado e resolvi construir o daqui. (...) Dr. Justino desenhou a planta para mim. Fui ao fiscal José Jorge de Matos e ele me mandou fazer um requerimento. O Dr. Simão da Cunha me deu autorização, com prazo de 10 anos e mais auxílio de mil e quinhentos réis. Isso foi lá por 1921 ou 22 (...). Esse coreto foi, por muito tempo, a alma de Figueira e de Governador Valadares. Ali a banda tocava a retreta e era o ponto de passeio dos jovens e até dos velhos da época. Era uma banda sem nome. (OCTAVIANO FABRI, citado por SOARES, 1983, p. 30)

Nas ocasiões de festa, os moradores de Figueira a recriavam, conferindo-lhe significados e valores que ultrapassavam a lógica da dominação do capital sobre o trabalho, a natureza e a vida. A criação, as alegrias são expressões de momentos de encontro entre diferentes, abrindo possibilidade para outras formas de sociabilidade:

É interessante recordar que o ano de 1924 ofereceu ao figueirense momentos de vibração e alegria para toda a comunidade... Primeiro foi o Carnaval. Na época apropriada aos festejos momescos, surgiram dois interessantes blocos: o Pierrô e o Leão da Folia. O Pierrô era um grupo muito envolvido com o futebol. Do personagem alma deste grupo só temos o sobrenome: Pires. Padeiro de profissão... Pois esse padeiro revelou existir nele um irrequieto folião com todo o potencial de liderança que exerceu com muita "cancha" no exercício total do comando da festa. Uma das músicas mais cantadas dizia:

"O padeiro trabalhava noite e dia

a fim de fazer pão para a sua freguesia.

A mulher dele, que nada fazia, cantava e pulava, de noite e de dia lá no bonde da Alegria e o padeiro não sabia... 
O padeiro quando soube, zangado, deixou de fazer pão, não atendeu mais à freguesia, deixou a profissão e foi ser fiscal lá no bonde da Alegria"

(OLIVEIRA, 1986, p. 12)

As festas eram maravilhosas e as professoras não tinham essa folga que têm hoje não. Ela era obrigada a comparecer no colégio toda uniformizada e nas festas cívicas faziam passeatas, discursos sobre as datas, hinos e ia pela rua afora marchando, cantando o Hino Nacional, o hino da Pátria. Conforme o dia que se comemorava, era aquele hino próprio. Era maravilhoso, coisa linda, mesmo! Isso quando era Figueira do Rio Doce. Quando passou a Valadares, a nossa escola fazia mais interno. Mesmo assim, durante muito tempo era obrigado que a professora comparecesse, assinasse o ponto e fizesse aquela hora cívica: hasteamento da bandeira e discurso para o menino declamar. Era uma coisa linda, linda, linda. No tempo de Figueira, passava aquela passeata e o povo às vezes enfeitava até as janelas, as portas, para comemorar as datas. Até as escolas particulares costumavam sair. (AURELIZA SIMÕES, professora aposentada)

\section{NO "BAR LIBAN S"}

Bar Libanês, 10 de fevereiro de 1935: trabalhadores decidem pela criação da União Operária": "associação de amparo econômico, defesa jurídica e assistência social à classe” (Estatuto da União Operária). Nesse mesmo dia, empossaram sua primeira diretoria provisória. Figueira acordou com uma alvorada de músicas. Eram os trabalhadores da cidade comemorando, pela primeira vez em Figueira, o dia do Trabalho. Os alunos das Escolas Reunidas Simão da Cunha saíram pelas ruas em passeata. Na segunda parte do dia, os trabalhadores saíram em passeata rumo à futura sede da União Operária para colocação da pedra fundamental. Lá deram posse aos primeiros delegados de profissão. (Livros de Atas da União Operária)

\section{APROPRIAÇÕES PARA O ENSINO DE HISTÓRIA}

Para essa discussão, colocaremos em evidência as possibilidades que a escrita híbrida da história - entre a memória e a História - pode oferecer tanto para formação de outra concepção de História e de tempo histórico - a história como labirinto - quanto para o aprendizagem da leitura indiciária, como método de investigação do conhecimento histórico. Nesse sentido, argumentamos que esta concepção - da história como labirinto - só poderá ser introjetada se colocarmos no coração das práticas do ensino de História a aprendizagem da leitura de sinais/signos, 
indícios, ruínas da história. Argumentamos que a aprendizagem dessa leitura poderá se iniciar pelo ato da leitura indiciária de um texto híbrido (a exemplo da escrita que acabamos de apresentar) para, em seguida, ser potencializada por outros procedimentos de investigação histórica, tal como os que pretendemos apresentar, de maneira muito breve. Para efeitos da continuação do nosso diálogo, convido aos leitores a voltarem à escrita apresentada (não o faremos devido ao espaço de que dispomos para a apresentação deste artigo), sempre que a ela fizermos menção. Convido os leitores, também, para pensarem sobre outras possibilidades de leitura oferecidas pelas memórias desses narradores - que certamente existirão - e/ou, ainda, sobre memórias contadas por outros narradores. E esse mesmo convite se estende para pensarem nas possibilidades que se colocam pela escrita híbrida a respeito da história de outras cidades: da sua cidade, da cidade na qual habitam os seus alunos.

\section{A HISTÓRIA COMO LABIRINTO}

O trabalho de exploração dessa escrita híbrida, entre a história e a memória, pode oferecer possibilidades de tomarem consciência do sentido histórico social e não-linear do tempo - essa categoria central do pensamento histórico. No lugar de um tempo representado por uma reta o tempo do progresso -, temos um tempo labirintítico, cheio de sinuosidades e que, para compreendê-lo, é preciso aprender a decifrar sinais, indícios e as mais aparentes insignificâncias: desde o rosto daqueles que circulam as ruas no presente, aos gestos, esquecimentos, pausas, olhares, um pedaço de papel retirado da gaveta pelo narrador, às ruínas presentes no espaço da cidade, aos sinais escondidos pelas camadas das intervenções humanas. A leitura dos sinais, dos indícios, requer o desenvolvimento das sensibilidades auditivas, visuais, de tatéis (por que não olfativas); requer a observação das minúcias, requer a curiosidade pelo inusitado, pelo desconhecido, pelo que se mostra estranho ou desconexo ${ }^{12}$. Segundo Benjamin, "o passado traz consigo um índice misterioso" (1994, p. 223) e, portanto, para dele nos apropriar é preciso, tal como o narrador, não desprezar os detalhes, as veredas por onde os caminhos se cruzam, se bifurcam e se fundem. A história das cidades é um lugar, por excelência, dos caminhos labirínticos, mesmo as cidades modernas. Os sinais do passado que o ligam ao presente, além de estarem na memória dos seus velhos moradores, podem estar em algumas poucas casas, edificações (pontes, passarelas, ruas estreitas e sem saída) que resistiram às rápidas exigências do progresso. Mas, só poderão ser identificadas por meio do desvelamento de 
suas várias demãos de pintura, nas suas camadas de reboco, de pintura, nas suas marcas deixadas intencional ou displicentemente pelas ruas da cidade e edificações da cidade (MATTOZZI, 2008). Pensemos nas casas da Rua da Direita, nos tijolos feitos à mão, na mistura certa, retirados um a um do forno a lenha no momento certo, de modo a lhes tornar resistentes às intempéries. Podem ser identificadas nas platibandas das casas, na madeira da qual foram feitas, como recordam os moradores a respeito do esmero dos carpinteiros vindos de Aimorés. Obras feitas de forma artesal, como é a narrativa dos que se forjaram nesse modo de produzir as riquezas.

"Assim, podemos, igualmente, somar nossa voz à de Resende (1999, p.156), quando inspirado por "As Cidades Invisíveis", de Ítalo Calvino, diz que as leituras da cidade e de sua investigação histórica “(...) não podem resumir-se ao jogo de economia ou as funções sociais de seus habitantes. As cidades possuem imaginários, cotidianos; são imprevisíveis, não-lineares”.

As narrativas orais, além de fornecerem elementos de desenvolvimento da acuidade para a leitura dos indícios, possuem, ainda, outros valores. Benjamin nos lembrará que uma das características fundamentais da narrativa... Reside na capacidade de relatar a estória sem ilustrá-la com explicações. (...) O extraordinário e o maravilhoso são sempre relatados com a maior exatidão, mas o relacionamento psicológico dos fios da ação não é oferecido à força ao leitor. Fica a seu critério interpretar a situação tal como a entende e, assim, a narrativa alcança uma envergadura ampla que falta à informação. (1975, p. 67)

A narrativa, ao ser aberta, múltipla, sem enquadramento, exerce o poder de incitar os alunos às perguntas, a se surpreenderem, a se espantarem, a suspeitarem da veracidade do narrado e, portanto a buscarem outros indícios para, em seguida, decifrar suas relações, buscar chaves de interpretação, buscar leituras outras para ajudá-los na construção de uma nova escrita - sempre híbrida - entre a história e memória.

Além disso, ao se indagarem dos outros indícios o farão com o olhar de hoje, no confronto com os indícios reveladores do tempo presente e, nesse sentido, poderão se indagar de como os habitantes daquela cidade (ele, o cidadão comum, os políticos), lidam com o passado, com o próprio presente e com o futuro.

O narrador, como vimos, conta o processo, a travessia, e não apenas o desfecho, o resultado, e oferece, em suas narrativas, relações pouco exploradas ou, por vezes, perdidas no tempo: desaparecimento da floresta tropical, surgimento da estrada de ferro, extinção de indígenas, disputa em torno da terra, dos consumidores de seus produtos e outras. Os narradores, ao relatarem os acontecimentos, ligam o início ao fim, ou 
melhor, o passado ao presente. A poluição do rio, a devastação da natureza, a expropriação do homem da terra que cultivava ganham, hoje, densidade maior, à medida que representam as perdas, as dificuldades que tiveram em realizar o que pretendiam. Portelli (1997, p. 31) argumenta que o que primeiro torna a história oral diferente das demais fontes é que ela nos conta menos sobre eventos que sobre "significados. (...) ela também é carregada de grande subjetividade do narrador e ela conta-nos não só apenas o que o povo fez, mas o que queria fazer, o que acreditava estar fazendo e o que agora pensa que fez". E essa fonte, quando versa sobre a história das cidades ou sobre a denominada história local, requer, como assinala Samuel Raphael,

(...) um tipo de conhecimento diferente daquele focalizado no alto nível de desenvolvimento nacional e dá ao pesquisador uma idéia muito mais imediata do passado. Ela encontra os seus ecos no mercado, ao ler o seu grafite nas paredes e seguir suas pegadas nos campos. (1990, p. 220)

Assim, a subjetividade, os "buracos" deixados pelos esquecimentos, os ecos das vozes do passado no presente e na memória podem nos levar a rever as nossas interpretações, a reordenar o que estava ordenado, a iluminar fatos novos ou desconsiderados e repensar a história como um campo de possibilidades. Vale lembrar que, na metade dos anos 80 do século passado, nos ensinava Déa Fenelon, ao se inspirar de Walter Benjamin e historiadores da nova história social inglesa, que "nada nos garante que o que triunfou foi sempre o melhor e que os projetos alter-nativos ou as lutas cotidianas, ainda que perdedoras, não devem merecer também a nossa atenção de historiadores" (FENELON, 1985, p.25). E por que não merecedoras da atenção dos professores no seu ofício de educar historicamente?

A narrativa oral oferece, ainda, a vantagem de apresentar-se numa linguagem coloquial, direta e carregada de imagens visuais, de referências espaciais e materiais, o que não só facilita a apreensão da matéria narrada, como também desperta emoções, prazer, sofrimento, solidariedade e inúmeros outros sentimentos e atitudes. $\mathrm{Na}$ visão benjaminiana, o narrador retira da sua experiência aquilo que ele conta, pois “(...) a narrativa mergulha a coisa na vida do narrador para, em seguida, retirá-la dele". Assim, se imprime na narrativa a marca do narrador, como a mão do oleiro na argila do vaso" (BENJAMIN, 1994, p. 205). Já em extinção no mundo pósindustrial, essa forma artesanal de narrar “....atinge-nos não apenas o pensamento, mas também sempre de novo a imaginação, a fantasia e as emoções, a espontaneidade e a inventividade, numa palavra, todas as camadas do humano" (GONÇALVES FILHO, 1988, p. 99). 
Nesse movimento de aprendizagem de leitura indicíária da cidade, fundada e apoiada nas narrativas dos velhos moradores, uma nova concepção de História pode ser adquirida pelos alunos. Todos esses indícios, sinais, ruínas do passado relatados pelos narradores necessitam de investigação focada numa tematização assentada numa problemática histórica, para a qual é imprescindível a mediação do professor. Pensemos num exemplo: a cartografia das referências culturais da cidade.

Vimos que a história narrada pelos depoentes não se ateve a uma cronologia precisa dos acontecimentos, mas nos ofereceu pontos de referência espaciais, tal como disse Maurice Halbwachs (1968) ao enfatizar que os pontos de referência estruturam nossa memória e a inserem na memória da coletividade a que pertencemos. Dito de outra maneira "A memória pendura-se em lugares, como a história em acontecimentos" (NORA, 1993, p. 25). Se a memória se enraíza no concreto, esses pontos de referência funcionariam como suportes a garantir sua sobrevivência. No entanto, talvez desses pontos não encontremos a não ser vestígios, ruínas e sinais na memória afetiva da cidade. Esses pontos expressam os territórios do medo (a fábrica de banha, as toras de madeira, a zona boêmia...), expressam os territórios conquistados (a visão de onde começa e termina a cidade, o rio, a praça de embarque), os territórios perdidos (o mercado, as matas ), expressam os territórios em ruínas (casas da Rua da Direita). Esses territórios são paisagens, edificações que se preservaram, são ruínas do que já foram, são “(...) impregnadas de memórias e significações que se constroem e se modificam pelas experiências e vivências sociais posteriores, exprimindo diferentes temporalidades" (FENELON, 1999, p. 289) ${ }^{13}$.

Nesse movimento de investigação pelos alunos da leitura dos indícios ou da marcas (na perspectiva defendida por Ivo Mattozzi no artigo que compõe o presente dossiê) do passado no presente da cidade, os alunos poderão oferecer aos seus moradores uma cartografia de suas referências culturais, dos documentos, monumentos, de uma prática de memória como História ${ }^{14}$. E nesse movimento de participantes da História, se educarem historicamente.

\section{CONSIDERACְ̃̃ES FINAIS}

Embora sob um viés analítico diferente do escolhido e desenvolvido por Nadine Fink, no artigo presente neste dossiê, esperamos ter contribuído igualmente para as práticas de história oral na escola. A história oral e as narrativas que ela nos oferece, fundadas na memória, além de possuir os valores, limites e riscos apontados por Fink (sobre os 
quais devemos estar vigilantes), propiciam aos alunos perceber a História como experiência. E a história das cidades parece-nos ser de enorme potencial para que os alunos reflitam sobre sua própria experiência histórica no lugar em que vivem, sobre suas responsabilidades no presente e na construção do futuro.

Esse modo de pensar as cidades nos parece de grande potencial para quem quer promover uma educação histórica sensível ao desenvolvimento da capacidade decifradora dos sinais, signos, artefatos de memória, sensível aos diálogos entre os tempos históricos, as gerações, criando pontes entre a casa e a escola, a criança e o adulto, tal como nos apresentam Gisela Pellizzon e Sonia Regina Miranda, num dos artigos que compõe o presente dossiê. Idéia essa que encontra o seu reforço em Le Goff, quando afirma que

Foi através da memória de meus pais - e ainda pelo contato com uma memória dos tempos da sua infância e da sua juventude que sobrevivia nos seus caracteres, nas suas idéias, nos seus comportamentos quotidianos - que se edificou pouco a pouco em mim um sentido da duração, da continuidade histórica e, ao mesmo tempo, das rupturas. (LE GOFF, 1987, p. 172).

\section{REFERÊNCIAS}

BENJAMIN, Walter. Magia e técnica, arte e politica. São Paulo: Brasiliense, 1985.

BENJAMIN, Walter. O narrador. São Paulo: Abril Cultural, 1975. (Os Pensadores, 48). BENJAMIN, Walter. Rua de Sentido Único e Infanncia em Berlim por Volta de 1900. Pref. Susan Sontag. Lisboa: Relógio d`Água, 1992.

BOSI, Ecléa. Memória e Sociedade: Lembranças de Velhos. 2 ed. São Paulo: Edusp, 1987. BRESCIANI, Maria Stella Martins. Londres e Paris no século XIX: O espetáculo da pobreza. 3 ed. São Paulo: Brasiliense, 1985.

CHARTIER, Roger. A bistória cultural: entre práticas representações. 2 ed. São Paulo: Difel, 1998. COSTA, Emília Viotti da. José Bonifácio: mito e história. In: Da Monarquia à República; momentos decisivos. 4 ed. São Paulo: Brasiliense, 1987. p. 55-58.

DEBERT, Giusta G. Problemas relativos à utilização da história de vida e história oral. In: CARDOSO, C. I. Ruth. A aventura antropológica. Teoria e pesquisa. São Paulo: Paz e Terra, 1986. p. 146-156.

DIAS, Maria Odila Silva. A interiorização da metrópole: 1808-1853. In: MOTA, Carlos Guilherme. 1822: Dimensões. 2 ed. São Paulo: Perspectiva, 1986. p. 160-184.

DINIZ, Clélio Campolina. Estado e capital estrangeiro na industrialização mineira. Belo Horizonte: Sistema Editorial da UFMG, 1981.

ENCICLOPÉDIA EINAUDI. Memória. História. Porto, Casa da Moeda, 1984, v. 1. FAORO, Raimundo. República Velha: Os fundamentos políticos. In: Os donos do poder; formação do patronato político brasileiro. 5 ed. Porto Alegre: Globo, 1979. V. 2, cap. XIV, p. 579.

FAUSTO, Boris. A revolução de 1930. Historiografia e história. 10 ed. São Paulo: Brasiliense, 1986.

FENELON, Déa R. Trabalho, cultura e história social: perspectivas de investigação, 
PROJETO HISTÓRLA; História e Historiografia: contribuições ao debate. São Paulo, n. 4, p. 21 a 45, jun. 1985.

FENELON, Déa R. São Paulo: Patrimônio histórico-cultural e referências culturais. Projeto História, São Paulo, maio de 1999.

FERNANDES, José R. Oriá. Um lugar na escola para a História Local. Ensino em Re-vista. Uberlândia. V. 4, n. 1, p. 43-51, jan./dez.1995.

FORTES, Bias Chrispim Jacques. Decreto n. 788 de 19 de outubro de 1894. Coleção das Leis e Decretos do Estado de Minas Gerais. Ouro Preto: Imprensa Oficial de Minas Gerais, 1895. p. 449.

GIESBRECHT, Guilherme. Relatório dos serviços executados na estrada de rodagem de Figueira-Itambacury, durante o ano de 1936, s.n.t.

GINZBURG, Carlo. Mitos, emblemas e sinais. São Paulo: Companhia das Letras, 1989.

GODOY, M. Pimentel; COELHO, Iphygênio Soares. Recursos minerais do Estado de Minas Gerais. Secretaria da Agricultura do Estado de Minas Gerais, janeiro de 1947.

GONÇALVES FILHO, José Moura. Olhar e memória. In: O olhar. São Paulo: Companhia das Letras, 1988.

GRAZIANO, José da Silva. Estrutura agrária e produção de subsistência na agricultura brasileira. 2 ed. São Paulo: Hucitec, 1980. Cap. 1 e 2.

GUIMARÃES, Manoel Luiz Salgado. Nação e civilização nos trópicos: o Instituto Histórico e Geográfico Brasileiro e o projeto de uma história nacional. Estudos Históricos, Rio de Janeiro, n. 1, p. 5-27, 1988.

HALBWACHS, M. La mémoire collective. Paris: PUF, 1968.

HARDMAN, Francisco Foot. Trem fantasma; A modernidade na selva. São Paulo: Companhia das Letras, 1988.

HOBSBAWN, Eric J. A cidade, a indústria, a classe trabalhadora. In: A era do capital: 1848-1875. Trad. Luciano Costa Neto. 3 ed. Rio de Janeiro: Paz e Terra, 1982. Cap. 3 e 12. IGLÉSIAS, Francisco. Cadernos de Minas. Três séculos de Minas. Belo Horizonte, Biblioteca Pública Estadual Luiz de Bessa, 1985. (Cadernos de Minas, 1).

LE GOFF, Jacques et alii. A nova história. Trad. Ana Maria Bessa. Lisboa, Portugal: Edições 70, 1984.

LE GOFF, Jacques. "Memória”. In: História e Memória. São Paulo: Editora da Unicamp, 1994. p. 423-483.

LE GOFF, Jacques. A História do Cotidiano. In: DUBY, George et al. História e Nova História. Lisboa: Teorema, 1985. p. 81.

LEFEBVRE, Henri. O direito à cidade. Trad. T.C. Netto. São Paulo: Documentos Ltda., 1969.

LIMA, Valentina da Rocha. Problemas metodológicos da história oral. Seminário de História Oral, Salvador, 1983.

LUCENA, Célia Toledo. Memória e História Local: Ensino e Pesquisa. In: Tópicos Educacionais. Recife, v.12, n. 1; 2, 1994.

MELLO e SOUZA, Laura de. Desclassificados do ouro; A pobreza mineira no século XVIII. 2 ed. Rio de Janeiro: Graal, 1986. V. 8.

MONTEIRO, Norma de Góes. Imigração e colonização em Minas 1889-1930. Belo Horizonte, 1973.

NORA, Pierre. Entre memória e história: a problemática dos lugares. Projeto História, São Paulo, n. 10. p. 7-28, 1993.

NUNES, Benedito. O tempo na narrativa. São Paulo: Ática, 1988.

OLIVEIRA, João Ângelo. Memórias. s. n. t.

PALAZZOLO, F. Nas selvas dos vales do Mucuri e do Rio Doce. Petrópolis, 1945. 
PEREIRA, Lígia Maria Leite. Algumas Reflexões sobre histórias de vida, biografias e autobiografias. In: História Oral, 3, 2000.

PESAVENTO, Sandra J. Muito Além do Espaço: por uma História cultural do urbano. Estudos Históricos, Rio de Janeiro, v.8, n. 16, p.279-290, 1995.

PIMENTA, Demerval José. A Vale do Rio Doce e sua história. Belo Horizonte: s. ed., 1981. POLLAK, Michael. Memória, Esquecimento, Silêncio. In: Estudos Históricos, Cpdoc/ FGV, São Paulo, Editora Revista dos Tribunais Ltda., Vértice, 1989/3.

PORTELLI, Alessandro. O que faz a história oral diferente. Projeto História, São Paulo, n. 14, p. 25- 39, fev. 1997.

RESENDE, Antonio P. Recife: os espelhos do passado e os labirintos do presente ou as tentações da memória e as inscrições do desejo. Projeto História. Revista Brasileira de História. Cultura e cidades. São Paulo, 5 (8/9), set. de 1984.

ROCHA, Rízzia S. O pensamento temporal de Walter Benjamin e Marcel Proust. Disponível em: <http://www.fw.uri.br/publicacoes/literaturaemdebate/6PENSAMENTOTEMPORAL.pdf $>$. (Acesso em: 12 de março de 2008).

RONCAYOLO, Marcel. Cidade. In: Enciclopédia Einaudi: Região. v. 8. Lisboa: Imprensa Nacional.

SAMUEL, Raphael. História local e história oral. In: Revista Brasileira de História. São Paulo: ANPUH: Marco Zero, p. 220- 356, 1990.

SCHIMIDT, Maria Auxiliadora; CAINELLI, Marlene. Pensamento e ação no magistério. São Paulo: Scipione, 2004. p. 111-124.

THOMPSON, Paul. A voz do passado. História Oral. Rio de Janeiro: Paz e Terra, 1992. VERGUEIRO, Laura. Opulência e miséria das Minas Gerais. São Paulo: Brasiliense, 1981. ZAMBONI, Ernesta. O ensino de História e a construção da identidade. História - série argumento. São Paulo: SEE/ Cemp, 1993.

\section{NOTAS}

${ }^{1}$ Dissertação defendida no programa de Pós-Graduação em Educação da UFMG, em novembro de 1988, orientada pela profa. Dra Eliane Marta Teixeira Lopes. Num movimento de retorno às minhas origens como pesquisadora do ensino de História, este trabalho é hoje por mim revisitado. Neste momento, várias leituras e reflexões foram feitas, como se poderá facilmente notar pelas datas de produções lidas e incorporadas, que abrem, por sua vez, possibilidades de continuidade de trabalhos na perspectiva anunciada.

${ }^{2}$ Empregamos o conceito de imaginário no sentido proposto por BACZKO, Bronislaw. Les imaginaires sociaux. Imaginário social diz respeito aos sistemas simbólicos e imagens de representação coletiva. Representação e imaginário são conceitos centrais para a História Cultural (inclusive de cidades), como assinalam Pesavento (1995) e Pesavento (2004), entre outros.

${ }^{3}$ A esse respeito, podemos ler: SIQUEIRA, S. Emigração: Sonhos e frustrações no retorno à terra natal. Area Domeniun, v. 3, p. 267-289, 2008; SIQUEIRA, S. O sonho frustrado e o sonho realizado: as duas faces da migração para os EUA. Nuevo Mundo-Mundos Nuevos, v. 07, p. 21, 2007; DOMINGUES, Devani Tomaz. Dos Estados Unidos da América para Governador Valadares: conexões e desconexões. 2008. Dissertação (Mestrado em Sociologia) Universidade Federal de Minas Gerais; SOARES, Weber. Da metáfora à substância: redes sociais, redes migratórias e migração nacional e internacional em Valadares e Ipatinga. 2002. Tese (Doutorado em Demografia) Universidade Federal de Minas Gerais. 
${ }^{4}$ O que pode ser constatado nos Parâmetros Curriculares Nacionais, nos currículos de História de várias Secretarias Estaduais e Municipais de Educação e em manuais didáticos da atualidade. ${ }^{5}$ Entre as produções que revelam mudanças na perspectiva conceitual e metodológica do uso da história local para o ensino da História, destacamos, entre outros autores, ORIÁ (1998), BITTENCOURT (1998), ABUD (1998) M. JANOT'TI (1998), que enfatizam como a história local, compreendendo aí a história da cidade, pode possibilitar mais amplas compreensão e análise da realidade e do cotidiano, por meio da assimilação de fatores socioculturais diversificados e integrantes da formação da identidade. Bittencourt (2004), Schimidt e Cainelli (2004), SIMAN, SCALDAFERRI, RIBEIRO (2006) nos alertam, dentre outros aspectos, para o perigo de se identificar História local somente como História do entorno, do que está próximo no espaço e enfatizam a para necessidade de articular a dinâmica desse lugar com os processos históricos de outras localidades e países; ZAMBONI (1993) que ressalta a importância da História local para que os alunos possam se situar no momento histórico na suas relações com múltiplas temporalidades e, ainda, desenvolverem o sentido de pertencimento e de identidade social.

${ }^{6}$ A partir da data da elaboração do trabalho até os dias atuais, o estado da produção a respeito da história da cidade e, sobretudo, da região do Vale do Rio Doce, encontra-se, certamente, diferente. Esses estudos versam sobre aspectos da colonização da região, os conflitos de terra havidos nos anos que antecederam e sucederam imediatamente o golpe militar de 1960. Podemos ler: BORGES, Maria. Eliza. L. ESPINDOLA, H. S. Representações do Universo Rural e Luta pela Reforma Agrária no Leste de Minas Gerais. Revista Brasileira de História, São Paulo, v. 24, n. 47, p. 303-326, 2004; ESPINDOLA, Haruf. S A história de uma formação socioeconômica urbana: Governador Valadares. Varia História, Belo Horizonte, v. 19, p. 148-162, 1998; ESPINDOLA, Haruf. S. A Colonização das Almas. Pós-História, Assis, v. 9, p. 115-126, 2001; ESPINDOLA, Haruf. S. Práticas Econômicas e Meio Ambiente na Ocupação do Sertão do Rio Doce. Caderno de Filosofia e Ciências Humanas, Belo Horizonte, v. 8, n. 14, p. 67-75, 2000. Não se pode deixar de considerar a importante produção gerada por pesquisadores do curso de História da Univale no levantamento de acervos documentais sobre o Vale do Rio Doce, realizado em arquivos locais, nos municípios de Governador Valadares, Peçanha, Itambacuri e Teófilo Otoni. Inventariamento dos acervos levantados no Arquivo Público Mineiro, Arquivo Nacional, Biblioteca Nacional e IBGH do Rio de Janeiro. Levantamento de arquivos locais em cidades e vilas da região do Rio Doce. Produção dos Inventários e Banco de Dados.

${ }^{7}$ Ver RESENDE, Maria Efigênia Lage. A contribuição acadêmica para o estudo de Minas Gerais. In: Revista do Departamento de História, v.1, p. 76-86, 1985.

${ }^{8}$ Todas as entrevistas realizadas, num total de 40, foram gravadas e transcritas, posteriormente. Em anexo da dissertação, apresento a relação dos nomes das pessoas, sua idade e a principal atividade exercida.

${ }^{9}$ Sr. João Ângelo faleceu no final do ano em que nos prestou seu depoimento. No momento da entrevista, ofereceu-nos um pequeno Caderno de Memórias e esse depoimento foi dele retirado.

${ }^{10}$ Em 1909, um ano antes do Congresso de Estocolmo, em que o Brasil apresentou ao mundo um estudo das suas jazidas minerais, os ingleses adquiriram as opções de compra das jazidas de minério de ferro de Itabira, no Vale do Rio Doce. Para explorá-las, criaram, logo em seguida, o Brazilian Hematite Syndicate. Para transportar o minério, firmaram contrato 
com a Companhia Vitória-Minas (da qual se tornaram os maiores acionistas), mediado pelo Governo Federal nas cláusulas desse contrato, ficou estabelecido: "a) modificações no traçado da estrada de ferro; b) construção de uma siderurgia no Brasil”. O governo mineiro, preocupado com as perdas que este contrato (do qual não participou) traria ao estado, decretou uma taxa de exportação para o minério de ferro muito superior ao que o Sindicato inglês esperava e, ao mesmo tempo, isentou de impostos toda companhia que criasse fábricas para fundição de minério de ferro (Cf. PIMENTA, 1981, p. 27-32). Nesse momento, fracassou o plano de exportação do minério, apesar de tantas alternativas de acerto. A exploração do minério e o prolongamento dos trilhos da Vitória-Minas até Itabira só foram concretizados no contexto da Segunda Guerra Mundial, a partir da assinatura dos Acordos de Washington (1942), entre os governos de Brasil, Inglaterra e Estados Unidos (DINIZ, 1981, p. 55-57).

${ }^{11}$ Convém ressaltar que, naquelas cidades onde já havia certa tradição de luta operária, esse tipo de associação assumiu características político-ideológicas mais claras, congregando tendências comunistas e anarquistas e superando, assim, o aspecto predominantemente assistencialista presente em outras associações. A esse respeito, ver DUTRA, Eliana de Freitas. Caminhos operários nas Minas Gerais - um estudo das práticas operárias em Juiz de Fora e Belo Horizonte. Belo Horizonte, 1988, p. 344-355.

${ }^{12}$ Um frutífero diálogo pode ser feito entre Ginzburg (1989), Proust (1984, entre outros). Podemos ler a respeito o artigo de Rízzia Soares Rocha, "O pensamento temporal de Walter Benjamin e Marcel Proust.

${ }^{13}$ Essa frase de Déa Fenelon encontra sua inspiração no instigante trabalho de $\mathrm{M}$. Roncayolo, parte do volume Região, da Enciclopédia Einaudi.

${ }^{14}$ A esse propósito, podemos fazer um interessante diálogo com o trabalho desenvolvido pelo Museu Histórico Abílio Barreto, por meio do seu projeto "Onde mora a minha história”. Ver GUERRA, Isabela T. Onde mora minha História. In: ANAIS do Seminário de Ação Educativa do Museu de Artes e Ofícios, Belo Horizonte: Mazza Edições, 2007, p. 104-108.

Recebido: $15 / 04 / 08$

Aprovado: 18/05/08

Contato:

Faculdade de Educação da UFMG

Campus Pampulha

Avenida Antonio Carlos, 6627

Belo Horizonte - MG

BRASIL

CEP: 31270-901

E-mail: lanacastrosiman@yahoo.com.br 